\title{
Taming the UK's war prerogative: the rationale for reform
}

\author{
Tanzil Chowdhury* \\ School of Law, Queen Mary University, London, UK \\ *Author email: tanzil.chowdhury@qmul.ac.uk
}

(Accepted 12 January 2018)

\begin{abstract}
This paper assesses the current state of the war prerogative, specifically focusing on deployment decisions. It outlines the constitutional position over troop deployments, scrutinises recent reform efforts and problematises the rationale underpinning those reforms. The paper proceeds along one simple normative claim: that against the backdrop of frequent interventions, the publication of the Iraq Inquiry and a series of Bills that have sought to statutorise deployment decisions, less use-of-force is better than more use-offorce, and constitutional arrangements ought to reflect this. The paper begins with an exegesis of the most recent attempt to bring deployment decisions onto a statutory footing, focusing on: (a) the difficulties and concomitant problems in defining 'conflict decisions'; and (b) whether it could make deployment decisions reviewable. The paper then seeks to examine the rationale for reform, arguing that the main impetus behind the series of efforts has been to democratise the process of troop deployments when instead they should focus on use-of-force reduction.
\end{abstract}

Keywords: Armed Forces Deployment (Royal Prerogative) Bill; royal prerogative; war prerogative; use of force; judicial review; constitutional convention

\section{Introduction}

It must be stated from the outset that the reader may perceive there to be an enduring pacifistic sentiment ${ }^{1}$ running through the heart of this paper. Whether that is a reasonable interpretation or not, this paper accepts that in an international order made of nation states, the use of force - from air strikes, to troops on the ground and all the variants in between - is a necessary evil presumed in the liberal order, and that such decisions are the prerogative of the state. ${ }^{2}$ This paper operates on a very simple premise: that less use-of-force is better than more use-of-force and, as such, our constitutional arrangements around troop deployments ought to reflect this. It does not require a Herculean effort to acknowledge that less militarised states have more flourishing societies. In the Institute for Economics and Peace's 2015 report, Global Peace Index, it stated that in societies

\footnotetext{
${ }^{1}$ Part of this sentiment stems from a scepticism of the broadening of the exceptions to the prohibitions of the use of force. These arguments at the international law level translate to justifications at the domestic level for the use of force. One example was the controversial deployment of the 'revivalist theory' that was used as a justification for the 2003 invasion of Iraq. See J Woo 'International law and the war in Iraq' (2002) 97 American Journal of International Law 63. International lawyers have also engaged with the claim that interpretations of the exceptions to the general proscription of the use of force are effectively covers for colonial endeavours, and that there are structural continuities between modern day use of force and force previously justified under imperial pursuits. See also N Berman 'In the wake of empire' (1999) 14 American University International Law Review 1521; A Orford Reading Humanitarian Intervention: Human Rights and the Use of Force in International Law (Cambridge: CUP, 2009) 18; G Gozzi 'The "discourse" of international law and humanitarian intervention' (2017) 30(2) Ratio Juris 186.

${ }^{2}$ Unless, of course, such a configuration of the liberal international order is transformed. For a critique of liberal world order, see P Mishra Age of Anger: A History of the Present (New York: Farrar, Straus and Giroux, 2017). For a defence of the liberal world order, see J Ikenberry 'The end of liberal international order?' (2018) 94(1) International Affairs 7.
} 
where Positive Peace is stronger, development goals are more likely to be achieved. These societies are more resilient when faced with crisis and have fewer grievances' and have 'better performance on wellbeing measures, gender equality and better performance on ecological measures. ${ }^{3}$ The effects of the use of force, not only on the recipient, as Libya most recently has illustrated, ${ }^{4}$ but also on the alleged aggressor, are clear. The economic impacts are apparent, as are the national security threats it may invite as a result. Of course, a state's use-of-force arrangements are only one part in the complex machinery of state and society and the determination of whether it is peaceful or not. However, it can be claimed, without any quantum leap, that particular constitutional arrangements governing the use of force and peaceful societies can be mutually reinforcing.

Liberal democratic polities that have inherited the legacies of social contract theory have always claimed that the use of force is a legitimate policy tool in upholding the state's obligation to protect its citizens. ${ }^{5}$ By extension, such an obligation within the liberal paradigm demands the need for operational efficacy and flexibility in military matters. The UK's 'war prerogative' is considered one of its most significant executive powers. A specific part of this, deployment decisions, is considered a matter of 'high policy" and, as such, a 'forbidden' area for common law review, ${ }^{8}$ not legally requiring any approval from Parliament in its engagement. Since the controversial First Gulf War, a series of legislative proposals (most recently the current Private Members Armed Forces Deployment (Royal Prerogative) Bill 2016-2017) and governmental and Parliamentary committee reports have sought to challenge the previous executive monopoly over deployment decisions. Indeed, since the turn of the millennium, there has been a greater desire to 'tame the prerogative'. ${ }^{9}$ Coupled with the airstrikes in Libya in 2011, ${ }^{10}$ ongoing airstrikes in Iraq and Syria and the recent publication of the Chilcot Inquiry (though it was silent on the jus ad bellum-in bello of the 2003 Iraq invasion), deployment decisions continue to invite much scholarly, political and public attention.

The pressing issue, for matters of such constitutional importance, ought to be what underpins these reform efforts. Some may tentatively claim that the frequency of military deployments is cause for concern, and that use-of-force reduction ought to formulate the end to which reform is directed. Others will take the democrats' approach, arguing that decisions of such gravity necessarily require scrutiny and legitimacy of the house (though this is not to suggest that Parliamentarians cannot be both pacifists and democrats). The paper therefore, seeks to determine what basis - democratisation or use-of-force reduction - informs the reform efforts and critically examine those impulses.

This paper begins with outlining the current constitutional configuration of the war prerogative, specifically focusing upon deployment decisions. Part of this analysis will discuss the strength of Parliamentary intervention in deployment decisions and detail its role, followed by an analysis of the most recent Parliamentary effort to statutorise deployment decisions, the Armed Forces Deployment (Royal Prerogative) Bill 2016-2017. The Lords' debate around the recent Private Members Bill highlighted, among others, the following anxieties with statutorising the power: (a) the challenges with defining combat or 'conflict decisions'; and (b) the prospective justiciability of such a power, all of which would compromise the state's apparent peremptory obligation to protect

\footnotetext{
${ }^{3}$ Institute for Economics and Peace Global Peace Index: Measuring Peace, its Causes and its Economic Values (2015) p 3.

${ }^{4}$ Foreign Affairs Committee Libya: Examination of Intervention and Collapse and the UK's Future Policy Options (HC 2016-17).

${ }^{5}$ W Blackstone Commentaries on the Laws of England, in Four Books, vol 1 (E Christian (ed), 13 ${ }^{\text {th }}$ edn, Strahan 1800) 252; for an alternative view which examines the state's use of force (or violence more generally) in the production of the homo sacer (the 'bare life') see R Van Munster 'The war on terrorism: when the exception becomes the rule' (2004) 17(2) International Journal for the Semiotics of Law 141.

${ }^{6}$ China Navigation v AG [1932] 2 KB 197. I will focus on one aspect of the 'war prerogative', specifically the deployment of troops abroad. For a discussion on the scope of the war prerogative see also R Joseph The War Prerogative: History, Reform and Constitutional Design (Oxford: OUP, 2013).

${ }^{7} R$ (on the application of Gentle) $v$ The Prime Minister [2006] UKHL 20.

${ }^{8}$ CND v Prime Minister of the United Kingdom [2002] EWHC 2777 (Admin).

${ }^{9}$ See Public Administration Select Committee Taming the Prerogative: Strengthening Ministerial Accountability (HC 2003-04).

${ }^{10}$ See Foreign Affairs Committee, above n 4.
} 
its citizens. The analysis of the Bill, which shares many similarities with a long line of similar Bills, will proceed on the basis of whether such a Bill addresses these two key anxieties. As for the definitional challenges, it will pay particular attention to the potential indeterminacy of key terms in the Bill such as 'conflict decisions', 'special conditions' and 'emergency conditions', the latter two identifying exceptions to the general rule which would otherwise require Parliamentary authorisation before engaging military forces. On the judicial review of deployment decisions, the paper will focus on how statutorising the prerogative may, if at all, affect the justiciability of the prerogative power, tentatively arguing that the Bill may permit the High Court to venture into areas typically considered 'no-go' areas of exclusive executive jurisdiction.

The paper then turns to problematising the underlying rationale for the reform efforts of deployment decisions. It argues that democratisation of deployment decisions, as the primary impulse and aim for statutorising the prerogative, is partially misplaced. The main basis of this claim is that by making Parliament involved in deployment decisions, though fully accepting that subjecting deployment decisions to parliamentary scrutiny would be a positive development, may tend toward providing a legitimacy for deployment decisions that are not necessarily legal under UN Charter-based justifications under international law - a position advanced by Murray and O'Donoghue. ${ }^{11}$ In keeping with the paper's central thesis, that less use-of-force is better than more use-of-force, this section instead argues therefore, that reform efforts ought to be predicated on use-of-force reduction as the end.

\section{The current state of the 'war prerogative'}

The 'war prerogative' is understood to mean 'the powers, sourced in the prerogative, to declare war and to deploy the armed forces'. ${ }^{12}$ Typically, as with most of the monarch's prerogative powers in contemporary constitutionalism, these are exercised on her behalf by her government ministers.

The history of parliamentary involvement in the exercise of the war prerogative was largely consistent for the 400 years prior to the 1950s. Parliament's involvement had been either to offer support or advice, to be kept informed and gauge public support, or to exercise its power to raise taxes for war efforts. ${ }^{13}$ However, there was no sense in which Parliament approved deployment decisions and indeed, in the exercise of these functions, they were often informed ex post factum. Parliamentary interventions began to change after the end of the Second World War. In 1950, after it had begun, Clement Atlee held a Commons vote over the Korean war. ${ }^{14}$ After the UK had taken military action over Egypt in 1956 following President Nasser's nationalisation of the Suez Canal, a motion was put to the Commons until the House was then adjourned. Numerous military interventions of varying levels of conflict, from the Falklands in 1982, Iraq in 1991 and 1998, Kosovo in 1999, Sierra Leone in 2000 and Afghanistan in 2001 did not compel the government to invite the legislature to vote directly on military deployments. Though a specific Bill was introduced following the four-day bombing campaign of Iraq in $1998,{ }^{15}$ the introduction of a non-binding parliamentary vote on the Iraq invasion in 2003 ended a 53-year hiatus of Parliament's role in deployment decisions and, at that point, only the second time in the UK's constitutional history ${ }^{16}$ where the Commons had voted on war and the first where the vote was held before the deployment.

\footnotetext{
${ }^{11} \mathrm{C}$ Murray and A O’Donoghue 'Towards unilateralism? House of Commons oversight of the use of force' (2016) 65(2) International and Comparative Law Quarterly 305.

${ }^{12}$ Joseph, above n 6, p 2.

${ }^{13}$ Joseph, above n 6, pp 96-106.

${ }^{14}$ Hansard HC Deb, vol 477, col 485, 5 July 1950.

${ }^{15}$ The Bill was defeated prior to its second reading as it sought to affect the prerogative: Military Action against Iraq (Parliamentary Approval) Bill 1999, available at https://www.publications.parliament.uk/pa/cm199899/cmbills/035/ 1999035.htm.

${ }^{16}$ There was a period from $1642-1649$ in which the powers of government, including the war prerogative, were assumed by the Parliament: Joseph, above n 6, pp 45-47.
} 
The complexion of the war prerogative therefore, has critically changed since $2003,{ }^{17}$ with the emergence of a new convention to consult the Commons. The convention was set ${ }^{18}$ when Tony Blair reluctantly invited Parliament to vote on whether or not to invade Iraq (the third bombing campaign in less than 13 years). This precedent was then applied ${ }^{19}$ in 2011 when British forces (as part of NATO) established a no-fly zone over Libya - though again, troops had been deployed two days before a Parliamentary vote took place - and was finally established ${ }^{20}$ when Parliament refused to permit air strikes in Syria in 2013 following claims that the Assad regime had used chemical weapons on US and UK-backed rebels. Importantly, the then Prime Minister David Cameron honoured Parliament's vote despite not being legally obliged to do so. Subsequent votes to conduct airstrikes in Iraq in 2014 on invitation by the Iraqi government, and in Syria in 2015, have arguably settled the convention. Despite the genesis of Parliament's consultative role in 2003, only from 2013 did a consistent convention materialise (especially as military deployments had occurred in Mali in 2013, and in Afghanistan from 2001).

The UK's current constitutional position over deployment decisions, therefore, seeks approval from the House of Commons pertaining to the possibility of premeditated action in which military forces are to be deployed in combat operations. Presumably, initially non-combative deployments which then turn combative would warrant subsequent parliamentary approval. Retrospective approval would only be sought in emergency situations (ie to protect critical national interests, prevent humanitarian catastrophe or self-defence). ${ }^{21}$ The current constitutional position has also been described negatively by what it cannot do. For example, parliamentary consultation and approval is not a legal requirement, and the Commons also lack the power of initiative over military deployment decisions. Further, there are no standards for the information Parliament would be privy to in such discussions. ${ }^{22}$ Despite this, however, the strength of the convention has been enough for some commentators to suggest that 'Parliament now decides when Britain goes to war'. ${ }^{23}$

The strength of the convention has also been recognised by its inclusion in the Cabinet Manual, which now states that 'the Government acknowledged that a convention had developed in Parliament that before troops were committed, the House of Commons should have an opportunity to debate the matter and said that it proposed to observe that convention except where there was an emergency and such action would not be appropriate. ${ }^{24}$ However, the consultative role of the Commons has found varying levels of favour ${ }^{25}$ and as recently as April 2016, the former Defence Secretary Michael Fallon voiced clear rejection of statutorising deployment decisions, raising concerns that such action would compromise its expediency, efficiency and potentially make it amenable to review by the High Court. ${ }^{26}$

However, in April 2017, the Foreign Secretary, Boris Johnson, informed BBC Radio 4 of the possibility of UK military action against Syrian Government forces if the US invited the UK's support, and that whether the government could take such action without seeking parliamentary approval, needed to be tested. ${ }^{27}$ On 14 April 2018, following a chemical weapons attack on Douma a week earlier, the

\footnotetext{
${ }^{17}$ For a detailed outline of legislative history, parliamentary and government reports on the war prerogative, see P Lagassé 'Parliament and the war prerogative in the United Kingdom and Canada: explaining variations in institutional change and legislative control' (2017) 70 Parliamentary Affairs 285.

${ }^{18} \mathrm{~J}$ Strong 'Why parliament now decides on war: tracing the growth of the parliamentary prerogative through Syria, Libya and Iraq' (2015) 17(4) The British Journal of Politics and International Relations 608; Murray and O'Donoghue contest that the Commons vote on Iraq created a convention: see Murray and O'Donoghue, above n 11, at 325.

${ }^{19}$ Strong, above $\mathrm{n} 18$, at 612 .

${ }^{20}$ Strong, above n 18 , at 614 .

${ }^{21} \mathrm{C}$ Mills 'Parliamentary approval for military action' (Briefing Paper, 7166) (2015) 32-33.

${ }^{22}$ J Strong 'Interpreting the Syria vote: parliament and British foreign policy' (2015) 91(5) International Affairs 1124.

${ }^{23}$ Strong, above n 18 , at 605 .

${ }^{24}$ Cabinet Office The Cabinet Manual (London: 1st edn, 2011) p 44.

${ }^{25}$ For a detailed outline of parliamentary and government reports on the war prerogative see also Lagassé, above n 17 , at $285-290$

${ }^{26}$ Hansard HC Deb, vol 608, col 11, 18 April 2016.

${ }^{27}$ J Landale 'Johnson: Difficult to say "no" to Syria strike' (BBC News, 27 May 2017), available at http://www.bbc.co.uk/ news/uk-politics-39730685 (last accessed 27 May 2017).
} 
UK Government launched air strikes on Syrian Government targets in order to 'alleviate the extreme humanitarian suffering of the Syrian people'. ${ }^{28}$ Though many commentators claimed this was illegal under international $\mathrm{law}^{29}$, this was entirely lawful under UK constitutional law. Thus, despite the incremental development of a seemingly strong convention of general parliamentary deference, the 2018 strikes substantially undermined it. ${ }^{30}$

\section{An exegesis of the Armed Forces Deployment Bill 2016-2017}

Despite the emergence of a convention, though with increasingly growing exceptions, that politically mandates parliamentary authorisation, the power to deploy troops is still exclusively within the government's jurisdiction - particularly as the 2018 strikes illustrate. The convention neither imposes a legal obligation on the government in its deployment decision, nor are such decisions reviewable in the High Court. Despite the to-ing and fro-ing ${ }^{31}$ of the Lords Constitutional Committee and former PMs and senior ministers, ${ }^{32}$ calls for a Bill to place the war prerogative on statutory footing have been frequent. Indeed, from 1999-2016 $6^{33}$ there have been eight Private Members Bills that have attempted to place deployment decisions on a statutory footing. By and large, all the Bills share a common objective to statutorise Parliament's role in deployment decisions. The few differences are largely cosmetic, differing primarily in nomenclature, whether approval is sought from both Houses or one, how the exceptions to parliamentary approval are framed ('urgency', 'security', 'emergency'), and the timesensitive nature of retrospective approval. An exegesis of the most recent Bill therefore, can be similarly levelled at the previous reform Bills; and though the recent 2016-2017 Bill made no further progress as Parliament was prorogued on 3 May 2017, it is reasonable to suggest that future Bills are likely to follow a similar trajectory.

The most recent of these attempts to reform the war prerogative power has been The Armed Forces Deployment Bill 2016-2017, introduced by the Liberal Democrat peer, Baroness Falkner of Margravine in May 2016. Like its predecessors, the Bill sought to place the current prerogative power to deploy troops in military conflict on a statutory footing. Positioning the prerogative

\footnotetext{
${ }^{28} 28$ Policy Paper Syria Action - UK Government Legal Position (14 April 2018), available at https://www.gov.uk/government/publications/syria-action-uk-government-legal-position/syria-action-uk-government-legal-position (last accessed 10 July 2018).

${ }^{29} 29$ D Akande The Legality of the UK's Air Strikes on the Assad Government in Syria (16 April 2018), available at https:// d3n8a8pro7vhmx.cloudfront.net/campaigncountdown/pages/2243/attachments/original/1523875290/Akande_Opinion_UK_ Government\%27s_Legal_Position_on_Syria_Strike_April_2018.pdf?1523875290 (last accessed 10 July 2018).

${ }^{30}$ Tanzil Chowdhury How the recent strikes on Syria undermine UK constitutional controls on military action (The Law of Nations Blog, 23 April 2018) <https://lawofnationsblog.com/2018/04/23/recent-strikes-syria-undermine-uk-constitutionalcontrols-military-action/> (last accessed 23 April 2018); Victoria Fikfak \& Hayley Hooper Whither the War Powers Convention? What Next for Parliamentary Control of Armed Conflict After Syria (UK Constitutional Law Blog, 20 April 2018) <https://ukconstitutionallaw.org/2018/04/20/veronika-fikfak-and-hayley-j-hooper-whither-the-war-powers-convention-what-next-for-parliamentary-control-of-armed-conflict-after-syria/> (last accessed 20 April 2018)).

${ }^{31}$ House of Lords Select Constitution Committee, Constitutional arrangements for the use of armed force (HL 2013-14); House of Lords Select Committee on the Constitution, Waging War: Parliament's role and responsibility (HL 2005-06).

${ }^{32}$ Strong, above $\mathrm{n} 18$, at 611 .

${ }^{33}$ Military Action against Iraq (Parliamentary Approval) Bill 1999, available at https://www.publications.parliament.uk/pa/ cm199899/cmbills/035/1999035.htm; three Private Members Bills from the Commons: Armed Forces (Parliamentary Approval for Participation in Armed Conflict) Bill 2004-2005, Armed Forces (Parliamentary Approval for Participation in Armed Conflict) Bill 2005-2006, available at https://www.publications.parliament.uk/pa/cm200506/cmbills/016/06016.ii.html, Waging War (Parliament's Role and Responsibility) Bill 2006-2007, available at https://www.publications.parliament.uk/pa/cm200607/cmbills/034/2007034.pdf, Constitutional Reform (Prerogative Powers and Civil Service etc.) Bill 2005-2006, available at https:/www.publications.parliament.uk/pa/cm200506/cmbills/222/2006222.pdf; and three further Lords Bills, Armed Forces Deployment (Royal Prerogative) Bill 2014-2015, available at https://www.publications.parliament. uk/pa/bills/lbill/2014-2015/0017/15017.pdf, Armed Forces Deployment (Royal Prerogative) Bill 2015-2016, available at https://www.publications.parliament.uk/pa/bills/lbill/2015-2016/0034/16034.pdf and Armed Forces Deployment (Royal Prerogative) Bill 2016-2017, available at https://www.publications.parliament.uk/pa/bills/lbill/2016-2017/0010/17010.pdf. 
power on a statutory footing would thus engage the De Keyser principle, ${ }^{34}$ displacing the executive's exclusive jurisdiction to deploy troops. In the Lords debate on the Bill, the key driver for reform, as well as addressing concerns about the lead up to the 2003 Iraq War, ${ }^{35}$ was to 'strengthen our democracy by codifying the power of the Prime Minister. ${ }^{36}$ It appears, therefore, that democratisation was the explicit basis for reform, with use-of-force-reduction, a secondary consideration.

The Bill ${ }^{37}$ consisted of five short clauses, the first of which referred to the requirement for parliamentary approval (specifically the Commons) for troop deployments ${ }^{38}$ for the use of force so long as: (a) it was outside the UK; and (b) such deployment would be regulated by the law of armed conflict this is what the Bill referred to as a 'conflict decision'. The second clause described the 'process of approval' which would have obligated the Prime Minister to present a report (hereafter 'deployment report') outlining the 'objectives, locations and legal matters', though the details of this would have been contingent on the circumstances. Thus, certain omissions in the deployment report could be warranted for strategic or security reasons. A simple majority vote by the Commons to approve the content of the PM's report would have authorised the use of force, though the Commons would also have been entitled to consult the Lords.

Clause 3 was arguably the most significant, in that it identified exceptions to seeking Commons approval. The general requirement of Commons authorisation could be circumvented if either an 'emergency condition' or a 'security condition' obtained. An emergency condition referred to a conflict decision that was 'necessary for dealing with an emergency' in which the imminent nature of it would render Parliamentary approval inappropriate. The security condition described a conflict situation in which 'public disclosure of information about the conflict decision could prejudice ... the effectiveness of activities which result from the decision or with which the decision is otherwise connected' or endanger the security or safety of UK forces, allied forces or those assisting allied forces. Importantly, the Prime Minister retained the exclusive power to determine whether or not to invoke either of these exceptions, though the Bill recommended that she or he consulted appropriate committees before doing do.

If either the emergency or security condition were to have been invoked, the Prime Minister would have been required to 'inform the chair of any committee the PM thinks appropriate' and to publish a report (hereafter 'emergency condition report' or a 'security condition report') citing why such an invocation had been made, with information about the conflict decision ('objectives, location and legal matters' as in clause 2 above). A caveat, however, would have been reserved for a 'security condition report', if the Prime Minister felt that the same circumstances continued to exist which warranted the initial invocation of the security condition, such that a report would compromise national security. Under other circumstances, however, (ie if it was an emergency condition or if the circumstances had since changed) a report would have to have been presented to the Commons within 30 days of when the conflict decision was made. Clauses 4 and 5 respectively exempted Common's approval for Special Forces (or assistance to Special Forces) and stipulated that the Bill was to apply to all of the UK.

The Bill aimed to provide 'greater deliberation by all', whilst also addressing the apprehensions that opponents and sceptics had, including the then Defence Secretary Michael Fallon, with statutorising the prerogative. Indeed, while Baroness Margravine stated that 'the country expects the House of Commons, their representatives, to be the place where the buck stops, not a single powerful individual, who himself was never held accountable for his judgment', ${ }^{39}$ she accepted that defining combat

\footnotetext{
${ }^{34}$ [1920] AC 508; for a more recent restatement of this, see also $R$ (Munir and Another) $v$ Secretary of State for the Home Department [2012] UKSC 32.

${ }^{35}$ Hansard HL Deb, vol 773, col 2257, 8 July 2016.

${ }^{36}$ Hansard HL Deb, vol 773, col 2272, 8 July 2016.

${ }^{37}$ Armed Forces Deployment (Royal Prerogative) Bill [HL] 2016-17 <http://www.publications.parliament.uk/pa/bills/lbill/ 2016-2017/0010/17010.pdf>.

${ }^{38}$ Defined in the Armed Forces Act 2006, s 374.

${ }^{39}$ Hansard HL Deb, vol 773, col 2275, 8 July 2016.
} 
decisions (hereafter 'conflict decisions') and the potential justiciability of decisions were legitimate anxieties that politicians would have with the Bill. The paper now proceeds to ascertain whether these anxieties would have been adequately addressed.

(a) Defining 'conflict decisions, security and emergency conditions'

Determining what constitutes a 'conflict' for the purposes of this Bill is problematic, and can perhaps draw parallels with international law's difficulties with defining war. ${ }^{40}$ The term's obscurantism had also been acknowledged by Parliament. A recent Common's briefing paper discussing Parliament's role in military action stated that 'the spectrum of potential military operations is vast', ${ }^{41}$ a view shared by the Joint Committee which was put together to draft a resolution on deployment decisions. Writing in response to an MOJ White Paper, the Joint Committee also accepted the difficulties in defining a 'conflict decision', ${ }^{42}$ stating that recourse to international law fared no better. ${ }^{43}$ The author of the Bill, however, did not appear to share these definitional concerns about how conflict decisions would be interpreted by judges, instead placing her faith in intuitive understandings of the word and analogising this with legal definitions of similarly contestable legal terms such as 'terrorism'. ${ }^{44}$

The Bill was also silent on the deployment of troops in non-combat roles. In 2001 for example, Parliament was not consulted on the expansion of UK military operations to Helmand province in Afghanistan, where troops had initially been deployed in a post bellum reconstructive capacity. Similarly, in 2013, British troops were deployed in a non-offensive capacity to train local personnel in Mali, though this later expanded to providing surveillance aircraft. ${ }^{45}$ Both decisions took place without any parliamentary debate. It would appear from the now defunct Bill that this type of deployment would not have required Commons approval, as such deployment would not have fallen under the law of armed conflict and would not therefore have constituted a conflict decision for the purposes of the Bill (though Hansard reveals the anxieties provoked by such types of deployment and the absence of Commons intervention in such a situation). ${ }^{46}$ Approval for non-combative deployments could have turned on whether the 'conflict decision' would be interpreted broadly to cover either of the Afghanistan or Mali deployments (assuming neither the security nor the emergency conditions were engaged), but the title of clause 1 of the Bill, 'Pre-deployment approval' would appear to suggest, for the lexically pedantic, that already-deployed troops were not covered.

In addition to the challenges with defining 'conflict decisions', there was the more prescient issue of examining when the 'security and emergency conditions' obtained - the would-be exceptions to parliamentary approval. Like the potential plasticity of 'conflict decisions', there may also have been legitimate anxieties about the readiness of the Prime Minister to engage either of the security or emergency exceptions. Giving the Prime Minister exclusive power to engage either of these exceptions implied executive innocence: ${ }^{47}$ 'there is always a danger that, by its very nature, those concerned with national security may bring forth measures that are not objectively justified' ${ }^{48}$ If, at its heart, the Bill was an attempt to strengthen parliamentary democracy, the Prime Ministerial exceptions may in fact have rendered the rule the exception. Lord Touhig, in supporting the Bill and criticising the reluctance to put the prerogative on legislative footing, stated that:

\footnotetext{
${ }^{40} \mathrm{C}$ Greenwood 'The concept of war in modern international law' (1987) 36 ICLQ 283. See also P Rowe Legal Accountability and Britain's War 2000-2015 (London: Routledge, 2016) p 3.

${ }^{41}$ Mills, above $\mathrm{n} 21$, at 4 .

${ }^{42}$ Joint Committee on the Draft Constitutional Renewal Bill Draft Constitutional Renewal Bill Volume 1 (HC 2007-08).

${ }^{43}$ Mills, above n 21, at 39-40.

${ }^{44}$ See A Greene 'The quest for a satisfactory definition of terrorism: $R v$ Gul (2014) 77(5) Modern Law Review 780; C Gearty 'Terrorism and morality' (2003) 4 European Human Rights Law Review 377.

${ }^{45}$ MOD Press Release, 25 January 2013.

${ }^{46}$ Hansard HL Deb, vol 773, col 2258, 8 July 2016.

${ }^{47} R v$ Governor of Wormwood Scrubs Prison [1920] 2 KB 305.

${ }^{48} A v$ Secretary of State for the Home Department [2004] UKHL 56.
} 
On these benches, we recognise that there are occasions when to protect the safety of our forces and for reasons of national security it would not be right to come to Parliament, but our worry is that this is now becoming the rule, not the exception. That is why we need a Bill such as this. In a statement published in December, I think, last year, the Ministry of Defence told us that there were 147 of our troops in embedded forces in various parts of the world - the large majority of them, 94, in coalition HQs. We do not even know where they are. ${ }^{49}$

The same could be said of the proposed legislation. In fact, the Bill appeared to go beyond the current convention by ascribing additional exceptions to the current arrangement, not just on emergency grounds but on security ones too. Notably, Baroness Margravine suggested that the failed vote on military action in Syria in 2013 could have been authorised under the emergency condition of the new Bill. ${ }^{50}$ Indeed, it has been the case that "critical national interests" or "national security" for the purposes of the emergency condition clause, have been broadly interpreted. ${ }^{51}$

The 'emergency condition' exception could have swallowed the general rule to consult Parliament in other ways too. The exception provision was described as a situation which would not allow for 'sufficient time' for Commons approval. One situation this could have referred to is anticipatory self-defence. Anticipatory self-defence has its basis in customary international law, ${ }^{52}$ though its frequent condemnation suggests the weakness of the doctrine. ${ }^{53}$ It claims that a state need not wait for an armed attack to occur before it can use necessary and proportionate force. However, anticipatory self-defence has many detractors, with claims that it dresses up illegal use of force in a 'veneer of legality ${ }^{\text {,5 }}$ and seeks to undermine the general prohibition on the use of force under the UN Charter and the Charter-based justifications. In spite of this, the current UK Attorney General ${ }^{55}$ has firmly placed the UK in support of this approach. The overall effect of the 'emergency condition', therefore, could be to provide robust parliamentary legitimacy (rather than legality) ${ }^{56}$ for a controversial doctrine which could in fact result in the overall increase of the use of force. As with anticipatory self-defence, similar arguments as to the legitimation of conflicts with tenuous or no legal basis under international law - such as the responsibility to protect doctrine and humanitarian intervention ${ }^{57}$ - could function as potential invocations under the emergency condition. These doctrines may shift the normative basis of justifying military interventions from a legal bases (tentative or otherwise) to emphasising a decision's 'robust democratic legitimacy'.

Of course, these arguments as to the indeterminacy of key terms is only a problem for MPs that seek to normalise the scrutiny and approval of troop deployments to Parliament. For the government, it could be said that, to a certain degree, it would have had the same effect as the current arrangement, in allowing them to exercise their exclusive jurisdiction over troop deployments through the security and emergency exceptions.

\section{(b) Common law review of troop deployment}

If the Bill were to have passed, a pressing question would be whether it would have made deployment decisions subject to review by the UK High Court. This would appear prima facie to be the case, as the Bill would have provided a legal yardstick against which to scrutinise deployment decisions.

\footnotetext{
${ }^{49}$ Hansard HL Deb, vol 773, col 2273, 8 July 2016.

${ }^{50}$ Hansard HL Deb, vol 773, col 2261, 8 July 2016.

${ }^{51}$ Mills, above $\mathrm{n} \mathrm{21, \text {at } 4 .}$

${ }^{52}$ The basis for this was the Caroline Incident.

${ }^{53} \mathrm{C}$ Gray International Law and the Use of Force (Oxford: OUP, 2008) p 121.

${ }^{54}$ Ibid, pp $160-166$.

${ }^{55} \mathrm{~J}$ Wright 'Attorney general's speech at the International Institute for Strategic Studies' (Institute for Strategic Studies, London 11 January 2017), available at https://www.gov.uk/government/speeches/attorney-generals-speech-at-the-international-institute-for-strategic-studies (last accessed 28 June 2018).

${ }^{56}$ Murray and O'Donoghue, above n 11.

${ }^{57}$ Murray and O'Donoghue, above n 11 , at 315-320.
} 
As it currently stands, deployment decisions are not justiciable and thus amenable for judicial review. ${ }^{58}$ One can take the determination of justiciability ${ }^{59}$ in UK common law review as primarily being based on: (a) the institutional competence and legitimacy of the courts to review a decision; (b) the courts' general deference to the executive on issues of national security; and (c) general judicial reticence over 'polycentric matters'. Rather than adopting a rigid approach on determining justiciability, the courts have instead opted for a pragmatic one, on the basis of subject matter and suitability in each particular case. ${ }^{60}$ Opponents of reviewing deployment decisions would, therefore, refer to the institutional limitations of the administrative court coupled with judicial deference over national security issues, as well as the courts' apparent aversion to polycentric issues, in maintaining the veil of non-justiciability over deployment decisions. Each of these three limitations is now addressed.

On the question of the High Court's institutional competence to review the war prerogative, 'the courts have tended to limit their consideration of its existence and scope to a broad assertion of the Crown's undoubted and exclusive prerogative to declare war and deploy the armed forces. They have not considered in depth or detail its precise existence or scope, as these have been taken as axiomatic, and matters over which the courts should properly defer to the Crown'. ${ }^{61}$ The court's 'ineptitude' was clearly asserted in CND v Prime Minister of the United Kingdom, when Richard J stated that 'it is unthinkable that the national courts would entertain a challenge to a Government decision to declare war or to authorise the use of armed force against a third country ... the nature and subject matter of such a decision require it to be treated as an indivisible whole rather than breaking it down into legal, political and military and other components'. ${ }^{62}$ Further, Lord Bingham in $R v$ Jones (Margaret) stated that 'the courts will be very slow to review the exercise of prerogative powers in relation to the conduct of foreign affairs and the deployment of armed services' ${ }^{63}$ However, in 2013, the Supreme Court in Smith v Ministry of Defence ${ }^{64}$ held that certain decisions of service personnel gave rise to negligence and breaches of human rights.

On the issue of judicial deference to the executive, especially over issues of national security - the so-called 'national security trump' ${ }^{65}$ - the courts have generally been reluctant to exercise their supervisory jurisdiction. Further, strict evidential requirements in judicial procedure may render certain types of sources inadmissible in such cases. ${ }^{66}$ This deference, however, has softened with Bancoult ${ }^{67}$ and more vociferously in Rehman, ${ }^{68}$ where Lord Steyn stated that national security issues would not automatically fall beyond the scope of High Court review.

On the question of UK public law's apparent reluctance to adjudicate over matters which are 'polycentric', this is also contested. Polycentric issues are described as matters that comprise a large web of interdependent relationships, such that a change to one factor produces an incalculable series of changes to other factors. ${ }^{69}$ Lord Diplock's speech in Council of Civil Service Unions v Minister for the Civil Service provides an erudite description:

Such decisions will generally involve the application of government policy. The reasons for the decision-maker taking one course rather than another do not normally involve questions to which, if disputed, the judicial process is adapted to provide the right answer, by which I

\footnotetext{
${ }^{58}$ Iraqi Civilian Litigation v Ministry of Defence [2017] EWHC 3289 (QB) at [60].

${ }^{59}$ See also Rahmatullah (No 2) $v$ Ministry of Defence and Another; Mohammed and Others $v$ Ministry of Defence and Another [2017] UKSC 1 at [8].

${ }^{60} \mathrm{R}$ (on the application of Abbasi) $v$ Secretary of State for Foreign and Commonwealth Affairs [2002] EWCA Civ 1698.

${ }^{61}$ Joseph, above n 6, p 111.

${ }^{62}$ [2002] EWHC 2777 (Admin) at [60].

${ }^{63}$ [2006] UKHL 16 at [30].

${ }^{64}[2013]$ UKSC 41.

${ }^{65}$ Council of Civil Service Unions and Others $v$ Minister for Civil Service [1983] UKHL 6.

${ }^{66}$ Joseph, above n 6, pp 139-142.

${ }^{67} R$ (on the application of Bancoult (No 2)) $v$ Secretary of State for Foreign and Commonwealth Affairs [2008] UKHL 61.

${ }^{68}$ Secretary of State for the Home Department $v$ Rehman [2001] UKHL 47.

${ }^{69} \mathrm{~L}$ Fuller 'The forms and limits of adjudication' (1978) 92 Harvard Law Review 353. 
mean that the kind of evidence that is admissible under judicial procedures and the way in which it has to be adduced tend to exclude from the attention of the court competing policy considerations which, if the executive discretion is to be wisely exercised, need to be weighed against one another - a balancing exercise which judges by their upbringing and their experience are illqualified to perform. ${ }^{70}$ 
deemed imminent for the purposes of the Act ${ }^{77}$ - in other words, there was sufficient time to seek Commons approval - what may the courts have said? Lord Bingham stated in Belmarsh that there should be strong deference to the Government's assessment of the nature of threats posed to national security because the executive are 'called on to exercise a pre-eminently political judgment'. However, whilst previously the courts would have been happy with legal assurances by senior civil servants affirming the nature of threats, ${ }^{79}$ recent case law has suggested that the courts are now more willing to challenge the deference that national security claims invite. ${ }^{80}$ What the Bill might have added in such judicial assessments of national security, therefore, was their determination of 'emergency' and 'imminence' (or 'not sufficient time' as it was couched in the Bill). Arguably, this would have compelled the courts to determine the nature of a threat that would require a normative assessment of whether the use of force was legal or not for the purposes of UK law. This would have heralded nothing short of a critical juncture in judicial review, by inviting domestic courts to rule on deployment decisions. On the basis of this, it is arguable that the anxieties of opponents of the Bill and the former Defence Secretary had some basis. 
claim by suggesting that democracies are not overall less war prone, just less so with other democratic states. The idea has its origins, mistakenly according to some commentators, ${ }^{85}$ in Immanuel Kant's 1795 essay, Perpetual Peace, though Kant made the claim in reference to republics with civil constitutions rather than democracies. Empirical studies have both supported ${ }^{86}$ and refuted this claim ${ }^{87}$ but 'democracy promotion', as an extension of the democratic peace theory, maintains considerable purchase in political discourse.

While it has been accepted that the use of force is a necessary evil in an international order of nation-states, use-of-force reduction ought to be the primary impulse of reform of deployment decisions. While it may appear that a Bill which subjects deployment decisions to parliamentary oversight would reduce the use of force, this is not necessarily the case. Beside the 2013 vote on military intervention in Syria (the coalition government's motion being defeated by a slim majority of 13 votes), Parliament has voted, in substantial majorities, for military intervention (Syria 2015, 397-223; Iraq 2014, 542-43; Libya 2011, 557-13; Iraq 2003, 412-149; Syria 2018 (ex post factum) 317-256). Additionally, there is no conceptual connection between democratisation and use-of-force reduction. In other words, greater legislative intervention in deployment decisions does not necessarily result in use-of force reduction. Further, institutional and political restraints mean that MPs may not always be able to vote freely. The conceptual and institutional-political restrains are now dealt with in turn.

Democratisation, it is argued, as the primary impulse may in fact result in more use-of-force by providing non-UN Charter-based justifications for deployment decisions with a patina of legitimacy (rather than legality). Murray and O'Donoghue articulate why there is no conceptual connection between democratising 'domestic use-of-force arrangements' (as they refer to it) and the reduction of the use of force. They argue that greater parliamentary involvement is actually being used to undermine the general prohibition of the use of force enshrined in Article 2(4) of the UN Charter. ${ }^{88}$ Other states who incorporate their democratic assemblies into deployment decisions often do so on the basis of UN Security Council authorisation. This is not necessarily the case with UK parliamentary oversight of the use of force, partially because of the dualist interaction between UK domestic and international law. Thus, the domestic use of force arrangements can potentially supplant international legal prohibitions on the use of force, rather than supplement it. ${ }^{89}$ The authors substantiate this claim with reference to the literature on the legality-legitimacy distinction. This identifies a key shift in the normative basis of state action from 'legal decisions' to ones that are 'legitimate' which are 'a combination of legal, political and moral considerations which do not necessarily align'. 90 'Legitimate decisions', therefore, are often couched in 'legalised language', though they may not be predicated on UN Charter-based legal bases (or even weaker non-Charter basis). Instead, they are legitimated by the approval of democratic assemblies. The authors therefore identify an essential symbiosis between the reforms of the war prerogative (such as the convention to consult Parliament) and the novel grounds developed for military action. This can, in effect, produce parliamentary acceptance of non-Charter-based justifications for military force. ${ }^{91}$

On the institutional and political restraints, an important factor in supplanting UN Charter-based deployment decisions with 'legitimate deployment decisions' is the control the UK Government has over the Commons. The government can couch deployment decisions in ways that cast opponents of its proposals as unpatriotic, ${ }^{92}$ make use of the whip on potential rebel backbenchers, frame the vote as an expression of party loyalty, tie it to a vote of confidence in the Prime Minister ${ }^{93}$ or even

\footnotetext{
${ }^{85}$ JL Ray 'Does democracy cause peace?' (1998) 1 Annual Review of Political Science 28; S Gates et al 'Democracy and peace: a more skeptical view' (1996) 33(1) Journal of Peace Research 6.

${ }^{86} \mathrm{R}$ Rummel 'Libertarianism and international violence' (1983) 27(1) Journal of Conflict Resolution 27.

${ }^{87}$ Rosato, above n 84.

${ }^{88}$ Murray and O'Donoghue, above n 11.

${ }^{89}$ Murray and O'Donoghue, above n 11, at 307.

${ }^{90}$ Murray and O’Donoghue, above n 11, at 309.

${ }^{91}$ Murray and O'Donoghue, above n 11 , at 311 .

${ }^{92}$ Murray and O'Donoghue, above n 11, at 324.

${ }^{93}$ This was the case with the 2003 vote during Tony Blair's premiership. See Strong, above n 18, at 614 .
} 
attach it to careerist aspirations. ${ }^{94}$ Perhaps most importantly, however, there are also informational limitations, whether necessary (on national security grounds) or strategic such that the

nature of commons debate precludes authoritative legal or security assessments, leaving parliamentarians beholden to summaries of the advice enjoyed by the executive ... in the final assessment drawing upon national interest and moral considerations as well as issues of lawfulness, MPs might therefore accept (as arguably some did in the context of Iraq) an action as legitimate notwithstanding a breach of international law. ${ }^{95}$

While one should not presume that all parliamentarians are readily predisposed to military action and unwilling to sacrifice party loyalty for their conscience, it is also important to accept that the Commons have voted for military action, bar once, in overwhelming majorities on several occasions since 2003. This is not necessarily to suggest that parliamentarians have little political agency, but rather to recognise the power of the government in Commons. This was implicitly accepted in the Iraq Inquiry when it acknowledged 'a distinction between [Tony Blair's] beliefs and the JIC's actual judgements' over Iraq's weapons of mass destruction capabilities in the representations made by the former Prime Minister Tony Blair to Parliament on the 24 September 2002. ${ }^{96}$ Even if Parliament's role is strengthened, therefore, institutional and political restraints, specifically the absence of comprehensive information (along with the control of government in the Commons) means that decisions may be inchoate. Thus, the role of Parliament in deployment decisions, even if a similar Bill were to pass, is hugely contingent on the good graces of the government which is all the while trying to legitimate its use of force. Democratisation therefore, as an end of reform efforts, underestimates the role of the government in Parliament and may merely ossify 'inevitable' legitimation of government prerogative power.

Further, tenuous non-UN Charter-based and controversial Charter-based justifications - whether they are expansive interpretations of Article 51 or controversial 'revivals' of old UN Security Council Resolutions $^{97}$ - could provide a quantitatively larger class of justifications to engage the emergency conditions in such a type of Bill. The democratisation of the process for deployment, therefore, rather than being an inhibition on a government power, could produce the opposite effect. If the goal is democratisation, one cannot presume that this would necessarily result in use-of-force reduction.

\section{Conclusion}

The Armed Forces Deployment (Royal Prerogative) Bill was the most recent in a long line of Bills to reform deployment decisions and part of a larger effort, beginning in $2003,{ }^{98}$ by the Labour government to reform the UK constitution. What the Bill allows us to envisage are the complexities of anticipating the multiple instantiations of 'conflict decisions' and to appreciate the latent problems in the Prime Minister's power to determine 'emergency' or 'security' exceptions to parliamentary approval of deployment decisions. For the purposes of common law review, such a Bill, it has been argued, would have warranted a radical departure from judicial deference to the executive. Importantly however, what it also highlighted is that there is no necessary connection between democratisation (through parliamentary intervention) of the war prerogative and use-of-force reduction. On a conceptual level, this is because the value placed on democratising the deployment process is primarily only of intrinsic value. The merits of parliamentary involvement on deployment decisions is 'a good in and of itself in legitimating governmental action. However, democratisation, it has been claimed, is of little

\footnotetext{
${ }^{94}$ Strong, above n 22, at 1136 .

${ }^{95}$ Murray and O'Donoghue, above n 11, at 325 .

${ }^{96}$ The Report of the Iraq Inquiry, above $\mathrm{n} 82$.

${ }^{97}$ Woo, above $\mathrm{n} 1$.

${ }^{98}$ See also Public Administration Select Committee, above n 9.
} 
instrumental value because the institutional and political restraints on parliamentarians under the UK's current constitutional arrangements are limiting - though of course parliamentarians have often voted with their conscience rather than their party. For these reasons, legislative intervention, while nobly subjecting such an important decision to parliamentary debate and approval, may do qualitatively little to the aim of use-of-force reduction.

This normative basis, with such a Bill, for military action would be more interested in legitimacy through parliamentary involvement - rather than UN Charter-based legality. In addition, the 'emergency condition' caveats could have been used to invoke tenuous legal justifications (non-Charter-based or based on expansive but controversial readings of the Charter) for intervention without parliamentary approval. A sole focus on democratisation in reform efforts as an end in itself, therefore, may actually yield a more frequent use of force.

Parliamentary interventions on deployment decisions, therefore, will always struggle to reduce the use of force. Use-of-force reduction can only be achieved, not through greater legislative intervention, but through a more invasive common law review. By providing clear and precise standards, the paper has begun to anticipate some of the ways in which judicial review could exercise a far greater supervisory jurisdiction to provide a procedural and substantive check on government deployment decisions. To that effect, this Bill, or similar Bills, may be useful. The perennial argument of this paper, that 'less use-of-force is better than more use-of-force' can only effectively be addressed, therefore, if the impulse for reform efforts is use-of-force reduction, rather than democratisation.

Cite this article: Chowdhury T (2018). Taming the UK's war prerogative: the rationale for reform. Legal Studies 1-14. https:// doi.org/10.1017/1st.2018.12 